\title{
ENVENOMATION BY Micrurus CORAL SNAKES IN THE BRAZILIAN AMAZON REGION: REPORT OF TWO CASES
}

Pedro Pereira de Oliveira PARDAL(1), Joseana Silva de Oliveira PARDAL(1), Maria Apolônia da Costa GADELHA(1), Líliam da Silva RODRIGUES(1), Darlan Tavares FEITOSA(2), Ana Lúcia da Costa PRUDENTE(2) \& Hui Wen FAN(3)

\begin{abstract}
SUMMARY
Two cases of proven coral snake bites were reported in Belém, Pará State, Brazil. The first case was a severe one caused by Micrurus surinamensis. The patient required mechanical ventilation due to acute respiratory failure. The second case showed just mild signs of envenomation caused by Micrurus filiformis. Both patients received specific Micrurus antivenom and were discharged without further complications. Coral snake bites are scarcely reported in the Amazon region and there is a broad spectrum of clinical manifestations, varying from extremely mild to those which may rapidly lead to death if the patient is not treated as soon as possible.
\end{abstract}

KEYWORDS: Envenomation; Coral snakes; Micrurus surinamensis; M. filiformis; Brazilian Amazon.

\section{INTRODUCTION}

Coral snakes are the main representatives of the Elapidae in the Americas, the genus Micrurus being the most important in terms of public health ${ }^{4,6}$. Due to their large geographical distribution, coral snakes may be found in diverse environments ${ }^{6,13}$. In Brazil, several species of Micrurus are found throughout the whole country and a great number of them live in the lowland rainforest or tropical jungle ${ }^{6}$. The Amazon region harbors the largest number of species of coral snakes, such as Micrurus spixii and M. lemniscatus, and the only species closely associated with water environments, the aquatic coral snake, M. surinamensis $s^{6,22}$. These species live sympatrically in the Amazon basin ${ }^{31}$. Coral snakes are largely fossorial and seldom seen, even in very dense areas.

In contrast to viperids, the fangs of coral snakes are short, hollow structures that are permanently fixed in position on the anterior maxillary bones, which is a feature of proteroglyphous dentition. The short and small-sized fangs usually represent low risk to individuals wearing footwear and clothing. Most coral snake bites in human beings occur on the hands and usually involve a snake that was intentionally picked up and handled. This may explain the low number of Micrurus snake bites recorded. In 2007, of 22,763 snake bites reported in Brazil, 136 were attributed to the genus Micrurus and were without fatalities ${ }^{5}$. Most cases were reported in the Southern region, where M. corallinus is predominant, 11 occurred in Pará State.

Studies on Micrurus specific toxins are limited due to the fact that these animals are difficult to capture and keep in captivity, and are known to produce only a small amount of venom. The genus Micrurus possesses a potent neurotoxic venom, which causes postsynaptic blockage of neuromuscular transmission by binding competitively to the acetylcholine receptors ${ }^{38}$. The venom of $M$. corallinus also has a neurotoxin with presynaptic activity. These neurotoxins mainly cause cranial nerve paralysis in envenomed individuals, leading to so-called myasthenic or neurotoxic facies.

The first sign of peripheral nervous system involvement is usually ptosis, often followed by ophthalmoplegia, dysarthria and dysphagia. The descendent progression of envenoming may lead to dyspnea. Death can be a consequence of muscle paralysis and respiratory arrest. Specific antivenom is produced by the immunization of horses with $M$. corallinus and $M$. frontalis venoms. For other species, including the Micrurus species of the Amazon region, studies on their mechanisms of action and the neutralizing effects of antivenoms are rarely available ${ }^{2}$. Clinical descriptions of patients bitten by Micrurus are still much needed and therefore we describe two cases in which the severity of envenomation varied considerably.

\section{CASE REPORTS}

Case 1: An 18 year-old male, Biology student, was reportedly walking on a university campus belonging to the University of Rural Amazon, Belém, Pará State, when he found an 80-cm coral snake (Fig. 1). In an attempt to capture the animal, he was bitten on the left thumb. Immediately, the patient pulled the snake off so the animal did not hold on to the site of the bite. Only one fang mark was visible. He did not

(1) Hospital Universitário João de Barros Barreto, Universidade Federal do Pará, Belém, Pará, Brasil.

(2) Laboratório de Herpetologia, Coordenação de Zoologia, Museu Paraense Emílio Goeldi, Belém, Pará, Brasil.

(3) Instituto Butantan, Secretaria de Estado da Saúde de São Paulo, São Paulo, SP, Brasil.

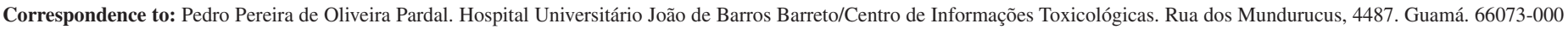
Belém, Pará, Brasil. Tel.: 55-91 3249.6370. E-mail: pepardal@ufpa.br 


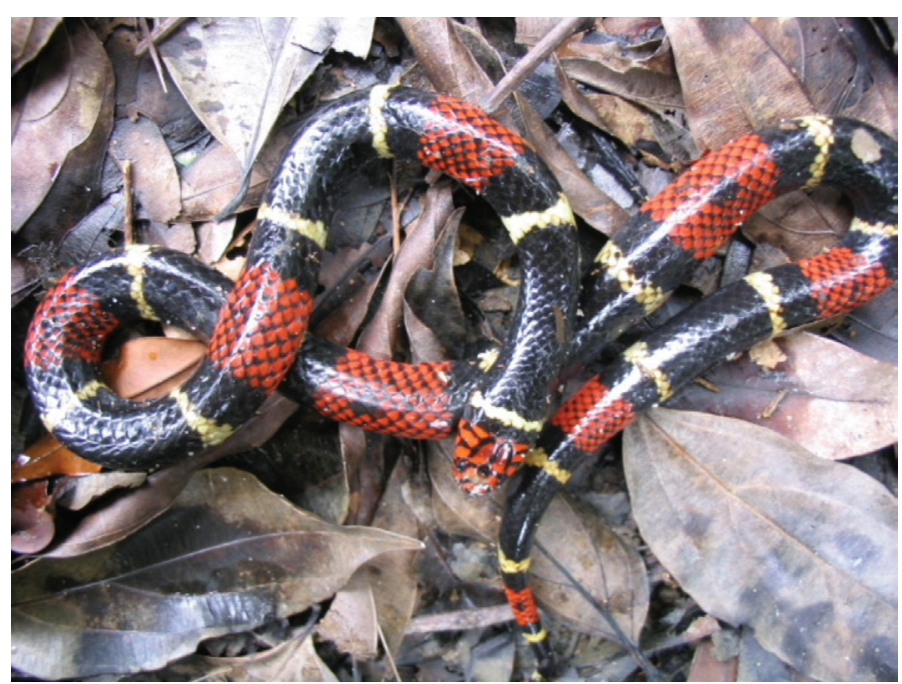

Fig. 1 - Micrurus surinamensis, specimen responsible for severe envenoming (Case 1).

complain of having any pain but he mentioned paresthesia at the bite site that went up along the whole limb a few minutes after the accident. He had been sent to the reference hospital, João de Barros Barreto University Hospital, where he arrived within 20 minutes after the bite took place, bringing with him a $M$. surinamensis coral snake. Upon arrival, he complained of blurred vision and difficulty in speaking, walking and opening his eyelids. On examination, he was in respiratory distress (40 mpm), foaming at the nose and mouth, conscious but unable to speak. He was not cyanosed or in shock. The pulse rate and blood pressure were normal $(100 / 80 \mathrm{mmHg})$. He was intubated and transferred to the Intensive Care Unit (ICU) where he was immediately put on a ventilator, followed by IV administration of neostigmine methylsulfate $(0.5 \mathrm{~mL}=5 \mathrm{mg})$, preceded by atropine sulfate $(1 \mathrm{~mL}=0.25 \mathrm{mg})$, and $100 \mathrm{~mL}$ of Micrurus

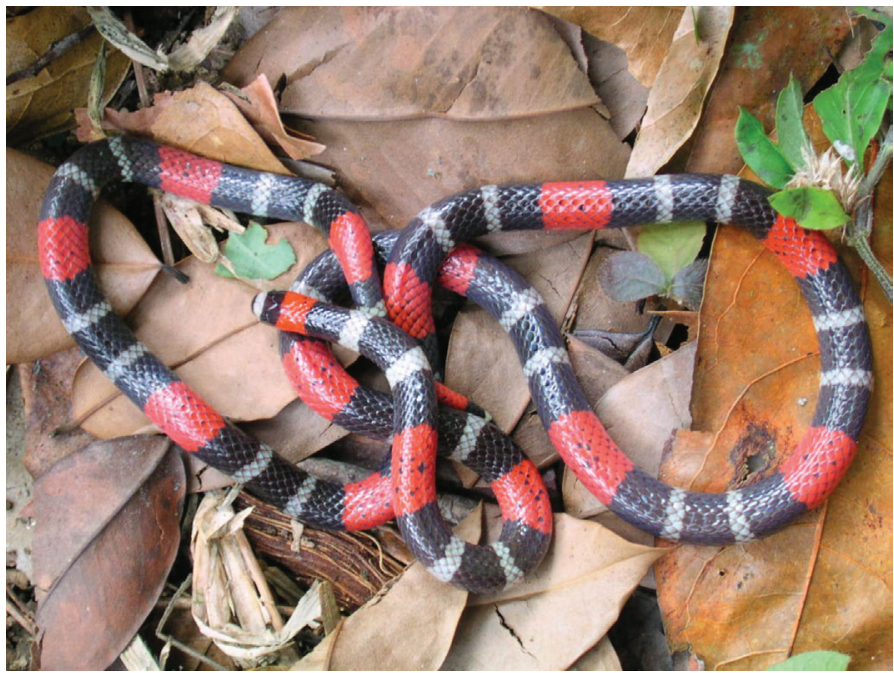

Fig. 2 - Micrurus filiformis, specimen responsible for mild envenoming (Case 2).

antivenom, produced by the Butantan Institute (São Paulo) in ampoules of $10 \mathrm{~mL}$ containing: $\mathrm{F}\left(\mathrm{ab}^{\prime}\right) 2$ horse antibodies, $1 \mathrm{~mL}$ neutralizing at least $10 \mathrm{mg}$ of $M$. frontalis reference-venom in mice. In the ICU the patient was found to be unconscious. The chest was clear and heart sounds were normal. Initial laboratory studies were normal (Table 1). Approximately $12 \mathrm{hrs}$ after the development of neurological symptoms, the patient was alert and following commands with a normal physical examination. Neostigmine administration did not apparently reverse any neurological manifestation. The patient could be weaned from artificial ventilation 48 hours after antivenom infusion. No further medication was required and the patient was discharged in a good condition on day 3 .

Case 2: A 19 year-old male was handling a colored snake which

Table 1

Laboratorial data from a patient bitten by Micrurus surinamensis (Case 1)

\begin{tabular}{|c|c|c|c|}
\hline \multirow[b]{2}{*}{ Test } & \multicolumn{3}{|c|}{ Date } \\
\hline & $\begin{array}{c}\text { 11/April/2006 } \\
\text { (before AV therapy*) }\end{array}$ & $\begin{array}{c}\text { 12/April/2006 } \\
\text { (24hrs after AV therapy) }\end{array}$ & $\begin{array}{c}\text { 13/April/2006 } \\
\text { (without artificial ventilation) }\end{array}$ \\
\hline \multicolumn{4}{|l|}{ Arterial blood gas analysis } \\
\hline $\mathrm{pH}$ & 7.36 & 7.51 & 7.41 \\
\hline $\mathrm{pCO}_{2}(\mathrm{mmHg})$ & 32 & 26 & 40 \\
\hline $\mathrm{pO}_{2}(\mathrm{mmHg})$ & 379 & 198 & 283 \\
\hline $\mathrm{HCO}_{3}(\mathrm{mEq} / \mathrm{L})$ & 18 & 21 & 25 \\
\hline Total $\mathrm{CO}_{2}(\mathrm{mmol} / \mathrm{L})$ & 19 & -- & 26 \\
\hline $\mathrm{BE}(\mathrm{mmol} / \mathrm{L})$ & -6 & & +1 \\
\hline Std. BE & -6 & -1 & +1 \\
\hline Std. BC & 20 & -- & 25 \\
\hline Sat. $\mathrm{O}_{2}(\%)$ & 100 & 100 & 100 \\
\hline $\mathrm{FiO}_{2}(\%)$ & 40 & 50 & 50 \\
\hline Hemoglobin (g/dL) & 13.2 & -- & -- \\
\hline Total leukocytes (count/mm³) & 18,500 & -- & -- \\
\hline Platelets $\left(\right.$ count $\left./ \mathrm{mm}^{3}\right)$ & 230,000 & -- & -- \\
\hline
\end{tabular}

\footnotetext{
*Patient was already on artificial ventilation.
} 


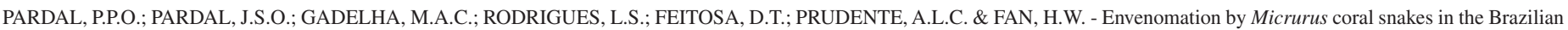
Amazon region: report of two cases. Rev. Inst. Med. Trop. Sao Paulo, 52(6): 333-7, 2010.

had been captured the day before in the village of Boa Vista in the Acará municipality, Pará State. He reported that he had been bitten on a lefthand finger and complained of mild pain. He stated that approximately one hour after the accident he noticed a mild swelling on the bitten limb and complained of epigastric pain. He mentioned two episodes of vomiting. Upon physical examination everything seemed normal apart from a small puncture wound on the fourth finger of the left hand with very mild edema. He had no blurred vision, ptosis or other symptom of neurotoxicity. He was given $100 \mathrm{~mL}$ of Micrurus antivenom and fully recovered while in the hospital. He was discharged 24 hours after the antivenom therapy with only mild edema on the hand, and remained asymptomatic. The snake was identified as a $50-\mathrm{cm}$ specimen of Micrurus filiformis (Fig. 2) by the Herpetology Laboratory of the Emílio Goeldi Museum, Belém, Pará State.

\section{DISCUSSION}

Two cases of human Micrurus envenoming are here presented, one caused by $M$. surinamensis and the other by $M$. filiformis, which show the potential for severe envenoming and the variability of the clinical manifestations. In Brazil, Micrurus envenoming is relatively rare and most cases are due to $M$. corallinus, M. lemniscatus and $M$. frontalis $^{6,9,20,32,39}$.

Although broadly distributed across the whole country, the number of Micrurus accidents is negligible, when compared to cases involving Bothrops and Crotalus snakes ${ }^{4}$. The rarity of human accidents is attributed to the type of dentition and envenoming which would result from a bite on a small part of the body, such as fingers, which enables the snake to hold on and to inoculate its venom into tissues by means of a chewing motion ${ }^{25}$. Contrary to this common view, Case 1 illustrates the capability of the coral snake in delivering a potentially severe bite without having to "chew" on the victim for a long period of time. Thus, envenoming should be diagnosed by the presence of the signs and symptoms of neurotoxicity. Fang marks may or may not be evident and when they are present, they are usually slight and may be seen as scratch marks. Even the absence of visible fang marks does not preclude the possibility of a bite with venom inoculation ${ }^{25}$.

Micrurus venoms are known to possess neurotoxic properties ${ }^{37}$. In most symptomatic cases neuromuscular paralysis is the most prominent and is caused by postsynaptic motor end-plate blockage of acetylcholine receptors, which produces similar effects to those seen in myasthenia gravis ${ }^{18}$ and curare poisoning ${ }^{24}$. This prevents nerves from stimulating muscle contraction and leads to paralysis. Similar actions are described for other Elapidae venoms, such as Naja and Bungarus spp ${ }^{14,19}$.

The two cases reported here presented different clinical aspects. The first progressed rapidly to respiratory distress while the other showed only mild edema without any neurological manifestations up to 24 hrs after bite. This broad spectrum of clinical manifestations in snake bites is generally known to occur. Cases of patients bitten by elapid snakes that did not receive antivenom and did not present neurological manifestations have been reported and characterized as asymptomatic or dry-bites ${ }^{6}$. It is important to point out that there are few studies available to understand the exact mechanism of action of Micrurus venoms, and some variation in their composition may be present among different species. Most experimental studies involve M. frontalis and M. corallinus venoms, since these two species are the most frequent cause of Micrurus envenoming in Brazil ${ }^{33}$. M. surinamensis venom is known to contain postsynaptic toxins ${ }^{33}$. One experimental study with Micrurus venoms from the Amazon, including M. spixii, M. averyi, M. lemniscatus and $M$. surinamensis, showed no coagulant activity but edematogenic effects, except for $M$. surinamensis ${ }^{2}$. Another study evaluated the biological and enzymatic activities of $M$. surinamensis venom but not those of $M$. filiformis ${ }^{8}$.

Antivenom administration is recommended as the most efficacious treatment for envenoming by coral snakes ${ }^{6,17}$. Specific Micrurus antivenoms, produced in Brazil by the Butantan Institute (São Paulo) and the Ezequiel Dias Foundation (Minas Gerais), are produced in horses immunized with the venoms of $M$. corallinus and $M$. frontali $^{29}$. However, some studies suggest that the neutralizing capacity of antivenoms may be improved by including venom from other Micrurus species in the venom pool used in the immunization protocol ${ }^{1,10,15,36}$.

The assumption that commercial antivenoms may be used in the treatment of bites by any Brazilian Micrurus species, even for other South American coral snakes contrasts with the scarcity of clinical studies on envenoming by Micrurus coral snakes, which are limited to case reports ${ }^{3,6,21,27,40}$. Unusual symptoms of envenoming by $M$. lemniscatus have been described ${ }^{21}$ in which the patient had severe pain in the bitten limb, despite repeated doses of potent analgesics, and no response to anti-cholinesterase or specific antivenoms was observed, either. In contrast, our patients had no intense local pain, but the Case 2 patient presented mild local swelling and pain, which is in accordance to experimental reports that have shown that some Micrurus venoms may induce myotoxicity and local lesions ${ }^{2}$.

Reports on Elapidae snake bites in Australia have suggested that pressure immobilization bandaging of the affected limb could impede the egress of toxins from the site of the bite and delay the onset of lifethreatening systemic involvement ${ }^{23,35}$. On the other hand, experimental studies have suggested that attaining the recommended pressure levels is technically very difficult and the effective use of this method might require extensive training and experience ${ }^{26}$. Because of this and time wastage concerns, in Brazil emphasis is given to improving antivenom supply and distribution, and instructions are that all victims should be transported to the nearest medical treatment facility as soon as possible.

Neurologic signs and symptoms of envenoming can be apparent in minutes, or be delayed for as long as 12 hours. In Case 1, the rapid onset of clinical manifestations indicates the severity of envenoming and the necessity of prompt intervention, not only with antivenom, but also with intensive care supportive measures. Moreover, improved methods of reversing the effects of neurotoxicity are needed. Even when administered early, antivenoms did not promptly reverse paralysis. Improvement in neurological signs was not seen until 24 hours after antivenom administration. Ancillary treatment has been recommended with anti-cholinesterase drugs; Edrophonium Chloride could benefit those patients bitten by a coral snake with postsynaptic neurotoxic venom ${ }^{41}$, and neostigmine had demonstrated the potential to reverse neuroparalysis ${ }^{9,39}$. Even when used in several occasions in clinical practice, no standard protocol has been followed. Our patient, for instance, had received a half dose of that used in other studies ${ }^{5}$. The failure of neostigmine in reversing neurotoxicity in Case 1 may be partially attributed to an insufficient dose. 
PARDAL, P.P.O.; PARDAL, J.S.O.; GADELHA, M.A.C.; RODRIGUES, L.S.; FEITOSA, D.T.; PRUDENTE, A.L.C. \& FAN, H.W. - Envenomation by Micrurus coral snakes in the Brazilian Amazon region: report of two cases. Rev. Inst. Med. Trop. Sao Paulo, 52(6): 333-7, 2010.

On the other hand, the very mild symptoms observed in Case 2 suggest that coral snake bites are not necessarily always severe. There is no generally accepted clinical classification for severity of accidents, and an empirical dose of 10 ampoules of antivenom is usually given, regardless of severity. A review of the classification of severity is thus needed to adjust the amount of antivenom to the real necessity in case of mild, moderate or severe envenoming, as exists for Bothrops and Crotalus envenoming.

Coral snakes are widely distributed in almost all major ecological regions of the New World, and a great number live in the lowland rain forest, particularly in the Amazon region of Brazil ${ }^{22}$. This area harbors the largest number of species of coral snakes, such as Micrurus spixii and M. lemniscatus, as well as the only species closely associated with water environments, the aquatic coral snake, M. surinamensis ${ }^{30}$. From all the Micrurus spp. that are found in Brazilian Amazon, M. surinamensis is one of the largest in girth and length, reaching up to $1,350 \mathrm{~mm}^{6}$. It inhabits humid tropical forests and secondary forests, near water flows of the Amazonas and Orinoco Rivers, in the Northern and Central parts of South America ${ }^{11,12,14,30}$. A proteomic analysis of the venom of the fisheating $M$. surinamensis provides an overview of its protein composition, the specific pharmacological features of which differ from other Micrurus species $^{28}$. Micrurus filiformis is also broadly distributed in the Amazon basin and may be found in secondary forests, low altitude mountains, open fields, and humid forests ${ }^{7,16,30}$.

In general, coral snakes are not abundant in nature, thus the scarcity of specimens is one reason why they are not well known, and their elusive habits are a key for their success in at least partially avoiding decimation by humans. But, as colorful and distinctive snakes, they sometimes appeal to humans to be handled and observed. With the increasing spread of the habit of keeping snakes as pets, it is important to identify elapids and distinguish them from false coral snakes, and also to spread information about first aid and treatment.

\section{CONFLICT OF INTEREST}

The authors of this study are not part of any association nor do they have commercial relationships that might represent conflicts of interest in the writing of this study

\section{RESUMO}

\section{Envenenamento por coral do gênero Micrurus na Amazônia brasileira: relato de dois casos}

Dois acidentes por coral verdadeira são descritos em Belém, Pará. O primeiro caso foi decorrente de envenenamento por Micrurus surinamensis, no qual a vítima necessitou ventilação mecânica por insuficiência respiratória. O segundo, causado por Micrurus filiformis, apresentou apenas manifestações leves. Ambos os pacientes receberam soro antielapídico específico e evoluíram sem complicações. Acidentes por coral verdadeira na região Amazônica são raramente descritos e podem cursar com um largo espectro de alterações, que variam desde quadros de envenenamento muito leves até manifestações com risco de óbito.

\section{ACKNOWLEDGMENTS}

The authors would like to thank all the health professionals of Hospital Universitário João de Barros Barreto, who contributed to the quality of patients' medical assistance. The authors are also grateful to Dr. Regina Dórea, for kindly reviewing the article.

\section{REFERENCES}

1. Abreu VA, Leite GB, Oliveira CB, Hyslop S, Furtado MFD, Simioni LR. Neurotoxicity of Micrurus altirostris (Uruguayan coral snake) venom and its neutralization by commercial coral snake antivenom and specific antiserum raised in rabbits. Clin Toxicol. (Phila). 2008;46:519-27.

2. Barros AC, Fernandes DP, Ferreira LC, dos Santos MC. Local effects induced by venoms from five species of genus Micrurus sp. (coral snakes). Toxicon. 1994;32:445-52.

3. Bolaños R, Cerdas L, Abalos JW. Venenos de las serpientes coral (Micrurus spp.): informe sobre um antiveneno polivalente para las Americas. Bol Of Sanit Panam. 1978:8:12833 .

4. Brasil. Ministério da Saúde. Manual de diagnóstico e tratamento de acidentes por animais peçonhentos. Brasília: Fundação Nacional de Saúde; 1998. 131p.

5. Brasil. Secretaria de Vigilância em Saúde. Sistemas de Informação. O que é o SINAN. Available from: http://dtr2004.saude.gov.br/sinanweb/index.php?name=Tnet (Acessed in 10 June 2007)

6. Bucaretchi F, Hyslop S, Vieira RJ, Toledo AS, Madureira PR, Capitani EM. Bites by coral snakes (Micrurus spp.) in Campinas, State of São Paulo, Southeastern Brazil. Rev Inst Med Trop Sao Paulo. 2006;48:141-5.

7. Campbell JA, Lamar WW. The venomous reptiles of the Western hemisphere. Ithaca: Comstock Publishing Associates; 2004. v.1, p.188-233.

8. Cecchini AL, Marcussi S, Silveira LB, Borja-Oliveira CR, Rodrigues-Simioni L, Amara $\mathrm{S}$, et al. Biological and enzymatic activities of Micrurus sp (coral) snake venoms. Comp Biochem Physiol Part A Mol Integr Physiol. 2005:140:125-34.

9. Coelho LK, Silva E, Espositto C, Zanin M. Clinical features and treatment of Elapidae bites: report of three cases. Human Exp Toxicol. 1992:11:135-7.

10. De Roodt AR, Paniagua-Solis JF, Dolab JA, Estévez-Ramirez J, Ramos-Cerrillo B, Litwin $\mathrm{S}$, et al. Effectiveness of two common antivenoms for North, Central and South American Micrurus envenomation. J Toxicol Clinical Toxicol. 2004;42:171-8.

11. Dixon JR, Soini P. The reptiles of the upper Amazon Basin, Iquitos region, Peru. II. Crocodilians, turtles and snakes. Contributions in Biology and Geology. Milwaukee: Milwaukee Public Museum Press; 1977. p.1-91

12. Gasc JI, Rodrigues MT. Liste préliminaire dês serpentes de la Guyane Française. Bull Museum Nat Hist Natur. 1980:4:559-98.

13. Harvey BH, Aparício EJ, Gonzalez L. Revision of the venomous snakes of Bolivia: Part 1. The Coral Snakes (Elapidae: Micrurus). Ann Carnegie Museum. 2003;72:1-52.

14. Hayashi K, Endo T, Nakanishi M, Furukawa S, Jorbert FJ, Nagaki Y, et al. On the mode of action of snake postsynaptic neurotoxins. Toxin Rev. 1986;5:95-104.

15. Higashi HG, Guidolin R, Caricati CP, Fernandes I, Marcelino JR, Morais JF, et al. Antigenic cross-reactivity among components of Brazilian Elapidae snake venoms. Braz J Med Biol Res. 1995;28:767-71.

16. Hoge AR, Romano-Hoge SARWL. Sinopse das serpentes peçonhentas do Brasil. Mem Inst Butantan. 1981;42/43: 373-497. 

Amazon region: report of two cases. Rev. Inst. Med. Trop. Sao Paulo, 52(6): 333-7, 2010.

17. Kitchens CS, Van Mierop LHS. Envenomation by the Eastern coral snake (Micrurus fulvius fulvius). JAMA. 1987;258:1615-8.

18. Kumar S, Usgaonkar RS. Myasthenia gravis-like picture resulting from snake bite. J Indian Med Assoc. 1968;50:428-9.

19. Lee CY. Elapid neurotoxins and their mode of action. Clin Toxicol. 1970;3:457-72.

20. Machado JC, Rosenfeld G. Achados anátomo-patológicos em necroscopia de paciente falecido por envenenamento elapídico. Mem Inst Butantan. 1970;35:41-53.

21. Manock SR, Suarez G, Graham D, Avila-Aguero ML, Warrell DA. Neurotoxic envenoming by South American coral snake (Micrurus lemniscatus helleri): case report from eastern Ecuador and review. Trans R Soc Trop Med Hyg. 2008;102:1127-32.

22. Melgarejo AR. Serpentes peçonhentas do Brasil. In: Cardoso JLC, França FOS, Fan HW, Málaque CMS, Haddad Jr V. Animais peçonhentos no Brasil. Biologia, clínica e terapêutica dos acidentes. São Paulo: Sarvier; 2003. p. 33-61.

23. Murrell G. The effectiveness of the pressure/immobilization first aid technique in the case of a tiger snake bite. Med J Aust. 1981;2:295.

24. Nedergaard OA. Curare: the flying death. Pharmacol Toxicol. 2003;92:10-15.

25. Norris RL, Dart RC. Apparent coral snake envenomation in a patient without visible fang marks. Am J Emerg Med. 1989;7:402-5.

26. Norris RL, Ngo J, Nolan K, Hooker G. Physicians and lay people are unable to apply pressure immobilization properly in a simulated snakebite scenario. Wilderness Environ Med. 2005;16:16-21.

27. Norris RL, Pfalzgraf RR, Laing G. Death following coral snake bite in the United States First documented case (with ELISA confirmation of envenomation) in over 40 years. Toxicon. 2009;53:693-7.

28. Olamendi-Portugal T, Batista CVF, Restano-Cassulini R, Pando V, Villa-Hernandez O, Zavaleta-Martinez-Vargas A, et al. Proteomic analysis of the venom from the fish eating coral snake Micrurus surinamensis: novel toxins, their function and phylogeny. Proteomics. 2008;8:1919-32.

29. Raw I, Guidolin R, Higashi HG, Kelen EMA. Antivenins in Brazil: preparation. In: Tu AT, editor. Handbook of Natural Toxins, vol. 5. New York: Marcel Dekker, 1991. p. $557-81$

30. Roze JA. A checklist of the New World venomous coral snakes (Elapidae), with description of new forms. Am Mus Novit. 1967;2287:60-95.
31. Roze JA. Coral snakes of the Americas: biology, identification, and venoms. Malabar, Florida: Krieger Publishing Company; 1996. p.1-328

32. Seligman R. Acidente por Micrurus frontalis: primeiro relato de envenenamento elapídico no Rio Grande do Sul. Mem Inst Butantan. 1993;55:65-8.

33. Silva Jr NJ, Griffin PR, Aird SD. Comparative chromatography of Brazilian coral snake (Micrurus) venoms. Comp Biochem Physiol B. 1991;100:117-26.

34. Silva Jr N, Bucaretchi F. Mecanismo de ação do veneno elapídico e aspectos clínicos dos acidentes. In: Cardoso JLC, França FOS, Fan HW, Málaque CMS, Haddad Jr V. Animais peçonhentos no Brasil. Biologia, clínica e terapêutica dos acidentes. São Paulo: Sarvier; 2003. p. 99-107.

35. Sutherland SK, Coulter AR, Harris RD. Rationalisation of first-aid measures for elapid snakebite. Lancet. 1979;1(8109):183-5.

36. Tanaka GD, Furtado MFD, Portaro FCV, Sant'Anna AO, Tambourgi DV. Diversity of Micrurus snake species related to their venom toxic effects and the prospective of antivenom neutralization. PLOS Negl Trop Dis. 2010;4:e622.

37. Vital Brazil O. Coral snake venoms: mode of action and pathophysiology of experimental envenomation (1). Rev Inst Med Trop Sao Paulo. 1987;29:119-26.

38. Vital Brazil O, Fontana MD. Ações pré-juncionais e pós-juncionais da peçonha da cobra coral Micrurus corallinus na junção neuromuscular. Mem Inst Butantan. 19834;47/48:13-26.

39. Vital Brazil O, Vieira RJ. Neostigmine in the treatment of snake accidents caused by Micrurus frontalis: report of two cases. Rev Inst Med Trop Sao Paulo. 1996;38:61-7.

40. Warrell DA. Epidemiology, clinical features and management of snake bites in Central and South America. In: Campbell J, Lamar WW, editors. Venomous reptiles of the Western Hemisphere. Ithaca: Cornell University Press; 2004. p. 709-61.

41. Watt G, Theakston RDG, Hayes CG, Yambao ML, Sangalanga R, Ranoa CP, et al. Positive response to edrophonium in patients with neurotoxic envenoming by cobras ( Naja naja philippinensis). A placebo-controlled study. N Engl J Med. 1986;315:1444-8.

Received: 26 November 2007

Accepted: 8 October 2010 